\title{
鋼製下地在来工法天井における野縁方向水平剛性評価法 EVALUATION METHOD FOR HORIZONTAL STIFFNESS OF CEILING WITH STEEL FURRING IN DIRECTION OF 'NOBUCHI'
}

\author{
元結 正次郎*, 佐 藤 恭 章** \\ Shojiro MOTOYUI and Yasuaki SATO
}

\begin{abstract}
Static loading tests for the typical unit of ceiling with steel furring subjected to horizontal force are executed to examine the initial horizontal stiffness of the ceiling in which diagonal members are added. As the experimental results, it is found that a joint metal part called 'hanger' have the great influence on the horizontal stiffness of the ceiling. Then, tests of the hanger connection are executed. The results show that the connection with a hanger leads to the different stiffness since contact points between the hanger and the channel member change depending on direction of loading. By investigating stress condition of hanger by the numerical analysis, the simple mechanical model is suggested for the hanger connection. The theoretical formulas were found for horizontal stiffness of a hanging bolt including the effect of hanger connection for the present mechanical model. Finally, the validity of the present formulas is shown through the comparison of the experimental results and theoretical results for some ceiling test specimen.
\end{abstract}

Keywords : Ceiling, Steel furring, Horizontal stiffness, Hanger connection

天井, 鋼製下地材, 水平岡性, ハンガー接合

\section{1. はじめに}

2011 年 3 月 11 日に起きた東北地方太平洋沖地震では、東北地方 から関東地方にかけての広範囲で様々な室内空間における天井落下 が多数発生した ${ }^{1)}$ 。特に注視すべき点は、気象庁による計測震度が 4 程度の首都圈でも大規模な天井落下が発生していること (写真 1)、 および、深刻な損傷が発生した天井が図 1 に示寸鋼製下地在来工法 天井として広く全国で用いられている仕様であったという点である。 これは近年の天井地震被害にも共通している事項である ${ }^{2)}$ 。のこ とは、主要構造体には損傷が発生しない程度の地震動によっても梁 刻な損傷の可能性を有寸る天井が日本各地に極めて多数存在してい るということを意味している。

こうした現状に対して、天井の落下対策に関わる技術基準告示 (以

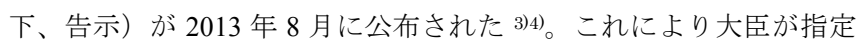
する「特定天井」については、技術基準にしたがった脱落防止対策 を講じ、地震応答解析等の構造計算の基準に天井の脱落防止の計算 を追加することが求められるようになった。特に重要な点は、告示 では鋼製下地間の接合金物が緊結状態を維持することが要求されて いる点である。しかしながら、このような法規制は新設の天井に適 用されるものであり、現存する鋼製下地在来工法天井においては、 従来の JIS A 6517 建築用鋼製下地材 (壁・天井) 5) (以下、JIS A 6517)

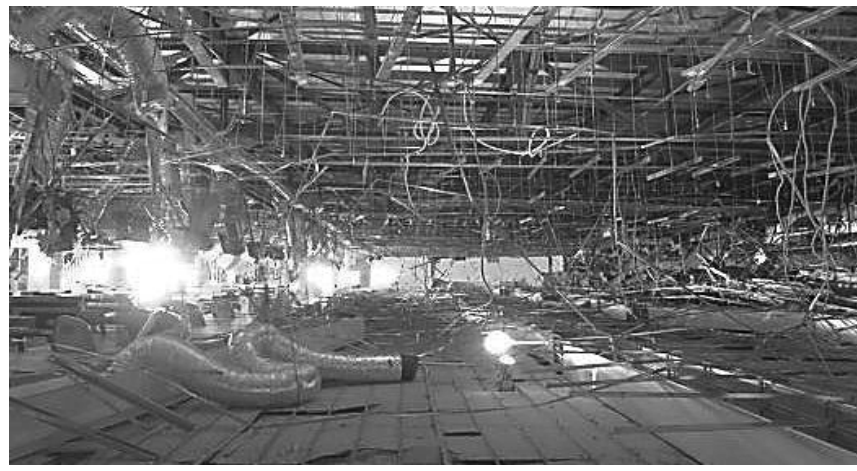

写真 12011 年東北地方太平洋沖地震被害例

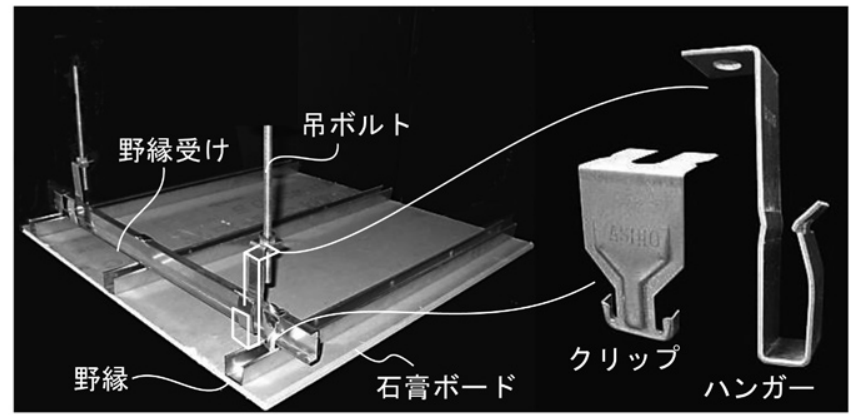

図 1 鋼製下地在来工法天井
* 東京工業大学大学院人間環境システム専攻 教授・工博

** 東京工業大学大学院人間環境システム尃攻 特別研究員 ·工修
Prof., Dept. of Built Environment, Tokyo Institute of Technology, Dr. Eng. Researcher, Dept. of Built Environment, Tokyo Institute of Technology, M. Eng. 
で規定されている力学的性状が不明な接合金物（図 1 のハンガーお よびクリップ）が一般に用いられているのが現状である。

一般に構造物の安全性を検討する上で、対象物に作用する外力の 設定、各部位に発生する応力の算定、各部位の耐力などの許容值の 設定が必要とされる。このうち天井面に作用寸る慣性力を求める際 に必要となる天井の固有周期すら精度よく推定することは困難な状 況にある。この理由は、鋼製下地在来工法天井においては上述した ように接合状態が曖昧な特有の接合金物を用いているためである。

そこで本研究では、JIS A 6517 にて規定されている鋼製下地在来 工法天井を対象として、固有周期算定に必要な水平剛性を簡便に算 定する方法を提示することを目的としている。具体的には、実験な らびに数值解析結果を踏まえて設定した単純な力学モデルを通して 水平剛性評価法を導出する。導出された本評価法から得られた剛性 を複数の実験結果と比較することで妥当性について検証する。

\section{2. 天井ユニット試験体による実験}

\section{1 実験概要}

はじめに、石膏ボードが野縁にビスで緊結されてできる天井面が 剛床として成立することを前提とする。そのもとで、ある大きな天 井の一部分を取り出した要素を天井最小ユニット試験体とし、その 試験体の水平剛性について検討する。図 2 に示すような $2 \mathrm{~m} \times 2 \mathrm{~m}$ の 小規模な天井ユニットの試験体を用いて、静的な水平加力実験およ び自由振動を行った ${ }^{6}$ 。

試験体は表 1 に示寸部材で構成されている。また、各部材は吊ボ ルト間隔 $900 \mathrm{~mm}$ 、野縁間隔 $330 \mathrm{~mm}$ 、天井懐 $1500 \mathrm{~mm}$ で組まれてい る。天井面は、 1 枚当たりの大きさ $1 \mathrm{~m} \times 2 \mathrm{~m}$ 、厚さ $12.5 \mathrm{~mm}$ の石膏ボ ード $\left(8.4 \mathrm{~kg} / \mathrm{m}^{2}\right)$ を用いて捨貼り (ボード 2 層貼) とした。試験体の総質 量はおよそ $92 \mathrm{~kg}$ であった。

静的加力の方法は、試験体の天井面にワイヤーを取り付け、滑車 を通した先に重りを載せていく方法とした。なお、載荷点は図 2 に 示寸点 $\mathrm{A} 、 \mathrm{~B}$ の 2 点において交互に錘を載せていくことで野縁方向 に繰返載荷を行った。

自由振動の際には、天井面と重りを繋ぐワイヤーを片系に換え、 糸を焼切ることで天井を振動させた。計測項目は、主に天井面の変 位と加速度とした。天井変位はレーザー変位計により天井面上の点 $\mathrm{A}$ の水平変位、加速度は天井面の点 $\mathrm{C}$ で加速度計を用いて計測した。

この実験では、ハンガー上面から斜め振れ止めの取付け金具まで の距離 $L_{b}$ （図 2）を変化させて、試験体の水平剛性を検討した。な お、斜め振れ止めの上端の取付け位置は、 $L_{b}$ のような吊ボルトの余 長が生じないように設置した。

$L_{b}$ は、斜め振れ止めを取り付けない状態の $L_{b}=1370 \mathrm{~mm}$ から 500 , 400, 300, 200, 100, 0 の 7 パターンを対象とした。なお、ここでは剛 性が線形な範囲を対象とし、それぞれの $L_{b}$ の試験体において、天井 面変位を $L_{b}$ にハンガー全長 $L_{h}$ を足した距離で除した層間変形角が 1/200 になるように最大変位を決めた。自由振動で与える初期変位 もこの最大変位を採用した。

\section{2 実験結果}

図 3 に各 $L_{b}$ に対する静的水平加力実験の結果を示す。ここでは、 $L_{b}=1370 \mathrm{~mm}, 400,200,0$ を代表として示している。 $L_{b}$ が大きくなるに つれて、剛性が低下していることが確認できる。これは吊ボルト部
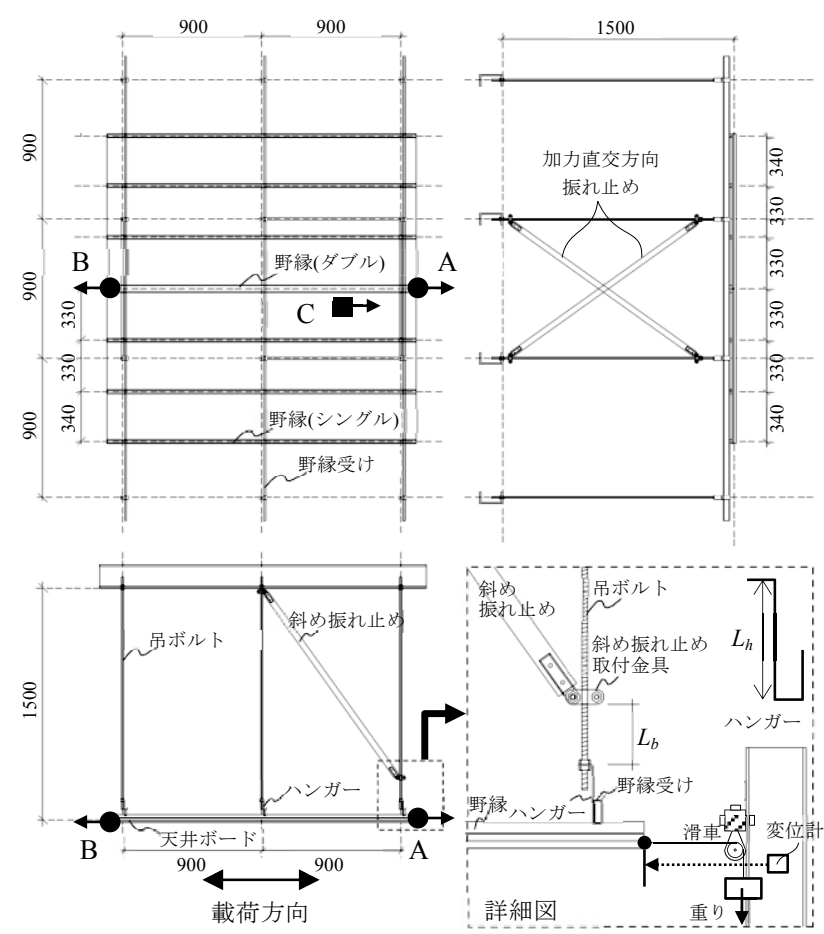

図 2 天井ユニット試験体の概要図

表 1 使用部材

\begin{tabular}{|l|r|c|r|}
\hline 天井部材名 & $\begin{array}{c}\text { 断面公称寸法 } \\
{[\mathrm{mm}]}\end{array}$ & 天井部材名 & \multicolumn{1}{|c|}{$\begin{array}{c}\text { 断面公称寸法 } \\
{[\mathrm{mm}]}\end{array}$} \\
\hline 吊ボルト & $\phi 9$ & クリップ(シングル & $23 \times 0.6$ \\
\hline 斜め振れ止め & $38 \times 12 \times 1.2$ & クリップ(ダブル) & $46 \times 0.6$ \\
\hline ハンガー & $24 \times 2.0$ & 野縁 (シングル) & $25 \times 19 \times 0.6$ \\
\hline 野縁受け & $38 \times 12 \times 1.2$ & 野縁 (ダブル) & $50 \times 19 \times 0.6$ \\
\hline
\end{tabular}

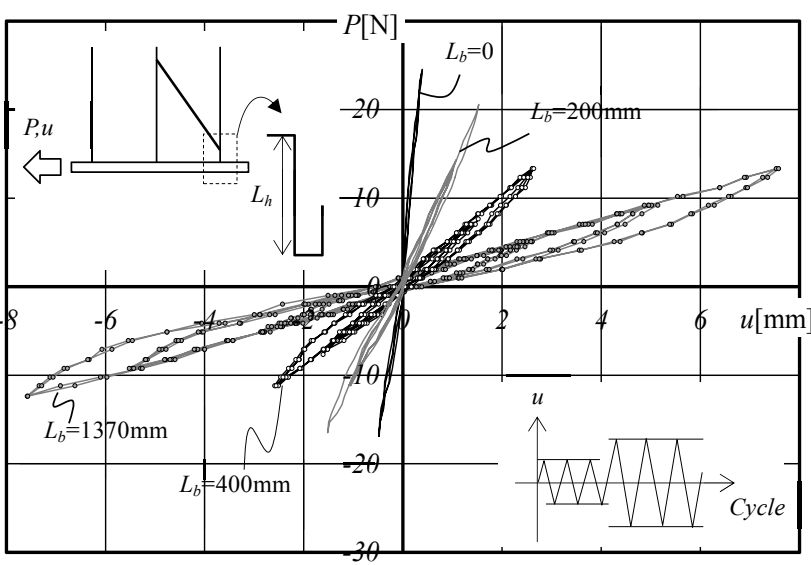

図 3 各 $L_{b}$ における天井の荷重変位関係図

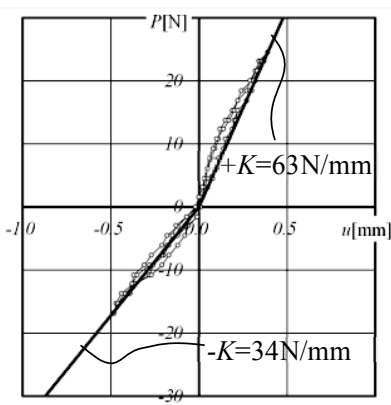

図 $4 \quad L_{b}=0$ の荷重変位関係図

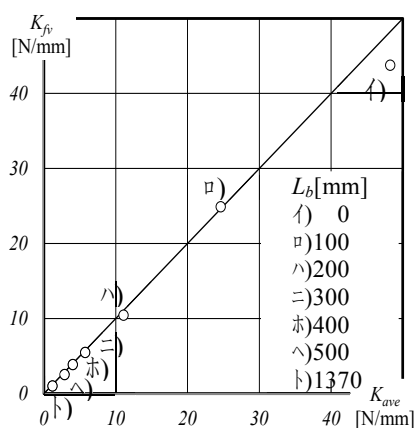

図 $5 \quad \mathrm{~K}_{\mathrm{Ave}}$ と $\mathrm{K}_{\mathrm{Fv}}$ の相関図 
分の $L_{b}$ が長くなるに伴い、吊ボルトの曲げ変形が支配的になってい ることが要因である。これは、 $L_{b}$ が天井の水平剛性に大きな影響を 及ぼす重要な值であり、天井の設計・施工過程において管理される べき内容であることを示唆している。図 3 では $L_{b}$ の值に関わらず、 それぞれの結果はほぼ線形となっているように見えるが、図 4 に示 すように $L_{b}=0$ の荷重変位関係は明確に異なる。 $L_{b}=0$ では、載荷の 向きによって剛性が異なっている様子がよく解る。吊ボルトの曲げ 変形がほぼない状態になり、ハンガー以下の部位の変形が支配的に なっている。したがって、ハンガーと野縁受けの接合部が天井の水 平剛性に方向性を与えていると考えられる。ここで、天井を 1 質点 系とみなし、両剛性 $(-K,+K)$ の相加平均值 $K_{A v e}$ を水平剛性として採用 することを考える。平均剛性 $K_{A v e}$ と自由振動から同定される天井の 水平剛性 $K_{f v}$ の相関関係を図 5 に示寸。なお、 $K_{f v}$ は固有振動数と天 井質量から求められる值である。同図によると $K_{A v e}$ と $K_{f v}$ の相関が 高く、 $K_{A v e}$ を 1 質点系の水平剛性として適用できることが解る。

\section{3. ハンガー接合部の要素実験 \\ 3. 1 ハンガー単体実験}

前章でハンガーと野縁受けの接合部（以下、ハンガー接合部）が 水平剛性に方向性を与えている可能性を示した。ここでは、ハンガ 一接合部を取り出した要素実験を行うことで、この部位の力学的特 性について検討する。

試験体は図 6a)に示寸野縁受けと八ンガーで構成されるハンガー 接合部である。この試験体を、オートグラフに装着させた専用の加 力治具に設置して加力を行った(図 6c) e)）。野縁受けが両端で固定 支持になるように、野縁受けのウェブをスペーサーと治具で挟むよ うにボルトで支持し、ハンガー上端もボルトで治具に固定支持した。 なお、野縁受けの両端を押さえているボルト間（i-j 端間）を野縁受 けの材長 $L_{c}$ とする。この実験における $L_{c}$ は $240 \mathrm{~mm}$ とした。載荷は ハンガー上端が固定された治具 $\mathrm{A}$ を強制変位させることで行った。 載荷パターンは図 6b)のような $5 \mathrm{~mm}$ 間隔の繰り返し漸増載荷とし、 それぞれ正方向から載荷を開始する場合と負方向から開始する 2 パ ターンを行った。計測に関しては、野縁受け両端に生じる反力の総 和 $H$ を治具 $\mathrm{B}$ の上部にあるロードセルで、治具 $\mathrm{A}$ の変位 $u$ をオー トグラフに内蔵された変位計で計測した。

実験から得られた荷重変位関係を図 7 に示す。いずれの載荷パタ ーンとも、正側載荷時の挙動と負側載荷時の挙動は全く異なる性状 を示している。正方向と負方向で明らかに初期剛性および耐力が異 なっている。これは、ハンガーが野縁受けと接触することで変形状 態が、ハンガーが閉じる状態（Close）と開く状態（Open）で異なる ことに由来すると考えられる。この特徴は前章の天井システムの挙 動と対応しており、ハンガー接合部固有の挙動であることが解る。

\section{2 ハンガー単体実験の再現解析}

複雑な挙動を持ったハンガー接合部を再現する数值解析モデルを 構築することで、ハンガー接合部の応力状態について数值解析的に 検討する。数值解析モデルの全体図を図 8 に示す。ハンガーと野縁 受けはともに梁要素とし、野縁受けは薄肉開断面であることから反 り変形を考慮する。境界条件は、野縁受けを部材中央の 1 点のみで $\mathrm{Y}$ 方向変位を拘束し、両端では材軸方向（Y 方向）の変位以外を全 て固定する。また、ハンガーの上端で X方向変位を許容する固定口 ーラーとする。載荷は、ハンガー上端で X方向に強制変位を与える。

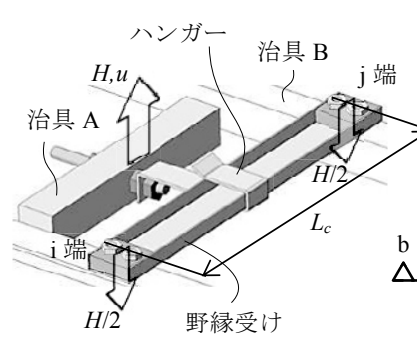

a) 試験体

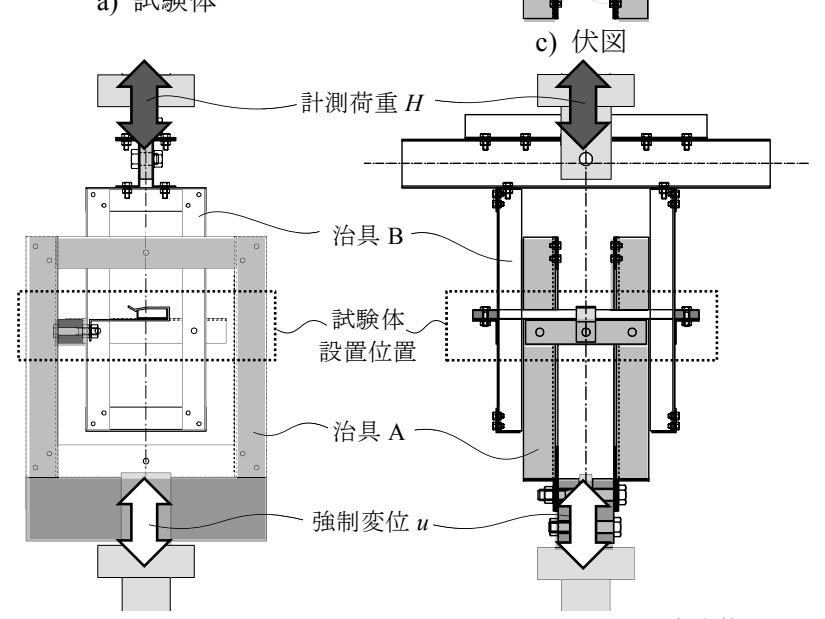

d) a-a'断面図

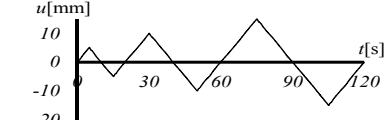

b) 載荷プログラム

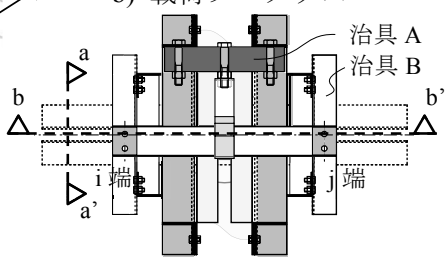

c) 伏図

e) b-b’断面図および試験体
図 6 加力装置と試験体

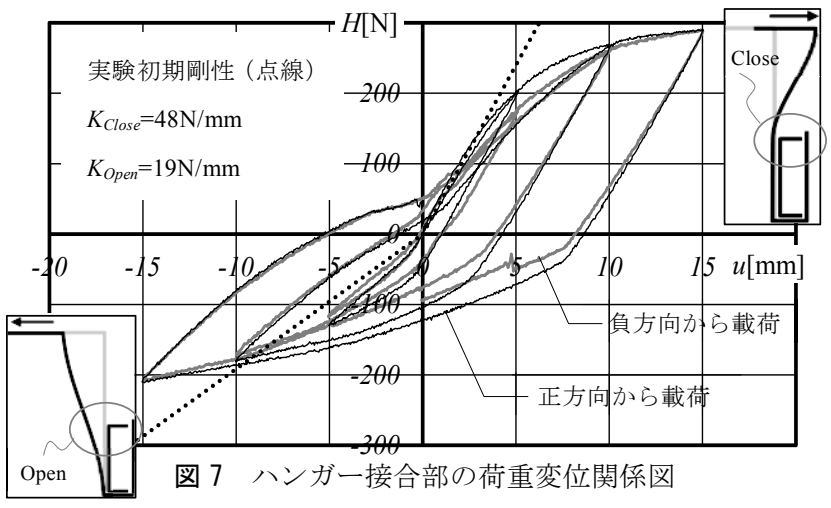

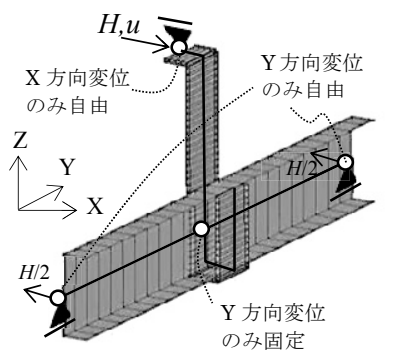

図 8 解析モデル全体図

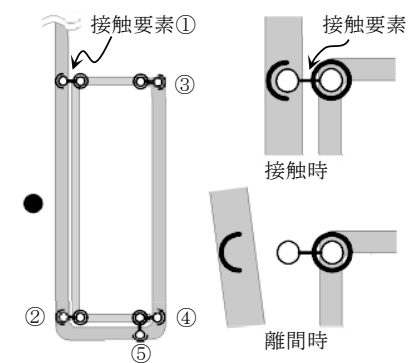

図 9 接触部の詳細図
表 2 材料特性

\begin{tabular}{|c|c|c|c|}
\hline $\begin{array}{c}\text { ヤング係数 } \\
E\left[\mathrm{~N} / \mathrm{mm}^{2}\right]\end{array}$ & $\begin{array}{c}\text { 降伏応力度 } \\
\sigma_{y}\left[\mathrm{~N} / \mathrm{mm}^{2}\right]\end{array}$ & $\begin{array}{c}\text { 等方硬化係数 } \\
E_{i}\left[\mathrm{~N} / \mathrm{mm}^{2}\right]\end{array}$ & $\begin{array}{c}\text { 移動硬化係数 } \\
E_{k}\left[\mathrm{~N} / \mathrm{mm}^{2}\right]\end{array}$ \\
\hline 205000 & 310 & $E / 100$ & $E / 100$ \\
\hline
\end{tabular}

載荷パターンは実験と同様である。材料特性および降伏応力度は、 表 2 に示すように既往の素材試験 7)で得られた数值を用い、混合硬 化則を採用した。実際の試験体からも解るように、ハンガーと野縁 受けの間は接触している。解析モデルでは、両者間に接触要素を図 9のように配することで両者の接触離間を考慮している。 
この数值解析モデルによって得られた荷重変位関係を実験結果と 比較したものを図 10 に示す。図 10 中の○は解析結果、実線が実験 結果である。太実線は後述する理論解による結果である。正負の初 期剛性值に加え繰り返し載荷中の挙動も両結果が精度よく一致して いることが解る。正方向負方向ともに実験結果の特徵である初期剛 性および除荷時の剛性の違いをよく捉えていることから、本数值解 析モデルが妥当であることが解る。また、実際の天井ではハンガー 接合部は天井の重量を支えていることから、天井の重量に相当する 鉛直力を図 8 の数值解析モデルに与えて天井の重量が水平剛性に影 響するか確認した。ハンガー1 個当たりにかかる天井の重量は約 150 [N/本]（天井ボード 2 枚貼、吊ボルト間隔 $900 \mathrm{~mm}$ 、野縁シング ル 2 本、野縁ダブル 1 本を想定）とし、ハンガーに鉛直力 $150 \mathrm{~N}$ が 生じるまでハンガー頂部を Z 軸の正方向に強制変位を与えた後、X 方向の強制変位を与えた。このとき得られた水平剛性は $\left(K_{\text {open }}\right.$, $\left.K_{\text {close }}\right)=(16,49)[\mathrm{N} / \mathrm{mm}]$ であった。これは、天井の重量を考慮してい ない結果 (図 10 中に記載) とほぼ等しいことから、水平剛性に対す る天井重量の影響は小さいと考えられる。以後、天井の重量は無視 して検討を行うこととする。

数值解析によって求められたハンガー金物に生じるモーメント分 布を各変形状態ごとに図 11 に示寸。ただし、この図は弾性域内の分 布で、最大のモーメントが生じる $\mathrm{B}$ 点を基準とした場合の各点にお けるモーメント比を表している。変形状態によって、ハンガーの境 界条件が変化しており、モーメントの分布が明確にことなっている ことが解る。ハンガーの Open 時では、点 $\mathrm{A} \sim \mathrm{E}$ で概袘しい材端モ 一メントが生じており、点 $\mathrm{C}$ で反曲点が生じている。要素 $\mathrm{AB}$ およ び DE のモーメントにわずかな勾配が生じている。これは点 $\mathrm{E}$ に生 じる鉛直の接触力に応じて点 A で鉛直方向に反力が生じているため であるが、モーメント勾配が緩く鉛直反力によるモーメント分布へ の影響は小さい。一方、Close 時では、要素 $\mathrm{AB}$ にモーメント勾配が なく鉛直反力および接触力が生じていないことが解る。また、 D 点 以降のモーメントが小さくほぼ曲げ変形せずに、野縁受けのねじれ 変形と共に剛体的に変位していることが考えられる。

\section{3 ハンガー接合部のカ学モデル}

数值解析によって明らかになったハンガー金物のモーメント分布 を考慮して、ハンガー接合部を図 12 に示すような力学モデルとして 考える。要素 $\mathrm{AB} \sim \mathrm{DE}$ はハンガーに相当する。この要素 $\mathrm{AB} \sim \mathrm{DE}$ 間は すべて剛接合とし、曲げ変形のみを考慮する。要素 $\mathrm{EF}$ は、ハンガ 一と野縁受けが一体となって剛体的に振る舞う部分である。点 $\mathrm{F}$ の 回転バネ剛性 $k_{\theta}$ は野縁受けの放じれ剛性を、水平バネ $K_{c}$ は野縁受 けの曲げ剛性をそれぞれ表す。ハンガー接合部の解析結果から、鉛 直反力による曲げモーメント分布への影響が小さかったことを受け て、鉛直反力をここでは考慮しないこととする。また、ハンガーは 載荷する方向によって、点 $\mathrm{C}$ でハンガーが野縁受けに接触・離間す るため、点 $\mathrm{C}$ における境界条件が変わる。そこで $+H$ の外力を受け て点 $\mathrm{C}$ が接触状態の時は、要素 $\mathrm{BC}$ と要素 $\mathrm{CD}$ 間の点 $\mathrm{C}$ で剛体にピ ンローラー接合されているとみなす。 $-H$ を受けて点 $\mathrm{C}$ が離間状態で はこの境界条件を無効とする。各要素のヤング係数 $E$ およびポアソ ン比 $v$ は全て等しいものとし、要素 $\mathrm{AB} \sim \mathrm{DE}$ ならびに野縁受け（弱 軸曲げ）の断面 2 次モーメントを $I_{h}, I_{c}$ とする。要素 $\mathrm{AB} \sim \mathrm{DE}$ の材長 は、距離 $\mathrm{BD}$ を基準とした長さ $L_{h}$ に比率 $\alpha, \beta, \gamma$ を乗じて表し、野縁 受けの材長は $L_{c}$ と寸る。なお、野縁受けのねじれ剛性は、サンブナ ンねじりと反り㸚じりを含めた㸚じりの一般方程式 8)を用いて求め

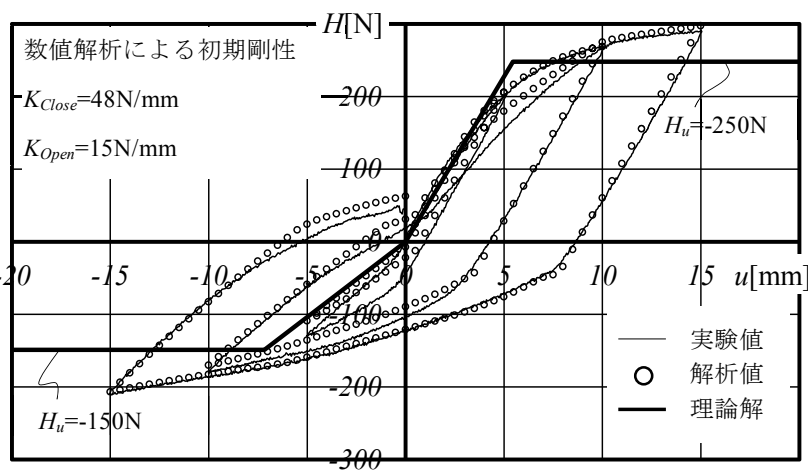

図 10 実験と解析結果の比較

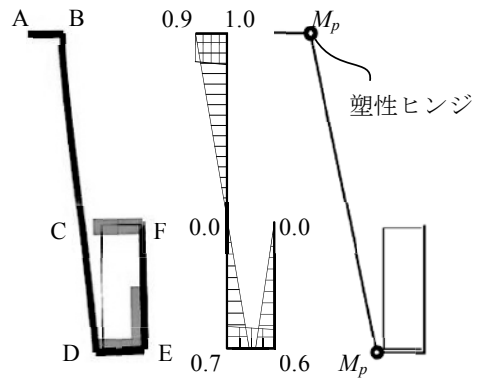

変形図 モーメント図 崩壊形

a) Open 時

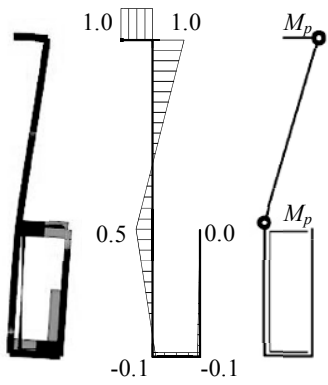

変形図 モーメント図 崩壊形

b) Close 時
図 11 変形図とモーメント分布図

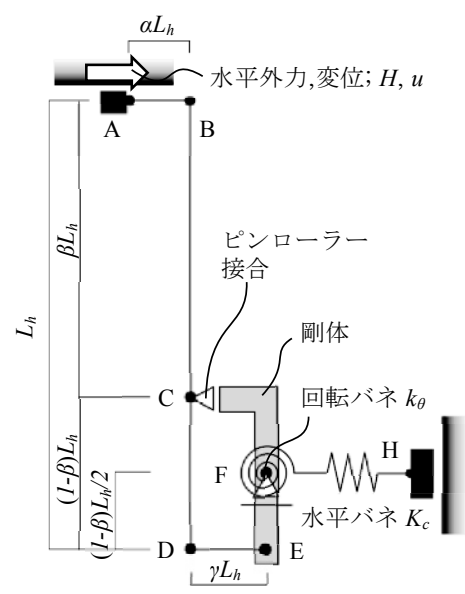

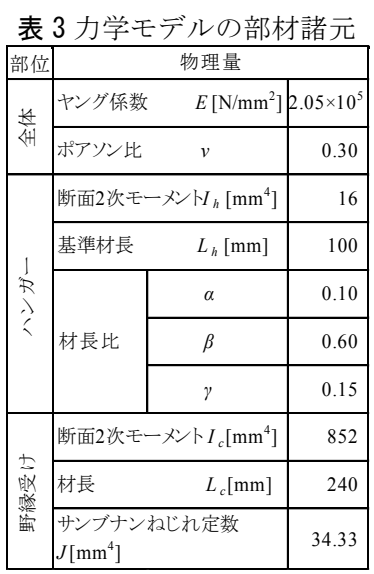

図 12 ハンガー接合部の力学モデル図

られる。本試験体では、野縁受け材端のウェブを金属板と治具フレ ームで挟むように固定したため（図 6a)）、材端条件に㸚じり回転を 拘束するが反りは自由とする単純支持を採用する。また、野縁受け の弱軸曲げに対しては、両端固定支持とみなす。最終的にハンガー 接合部の水平剛性を求める際には、表 3 に示した試験体の情報を各 変数に与える。以上、このモデルの点 $\mathrm{A}$ に荷重 $H$ が作用する場合に ついてたわみ角法により解く。ハンガー接合部の水平剛性式の導入 過程は付録 $\mathrm{A}$ に記し、得られた水平剛性式を次に示す。

$$
\begin{aligned}
& \text { open }_{S}=\left\{\frac{1}{K_{h 1}}+\frac{1}{K_{h 2}}+\frac{1}{K_{h 3}}+\frac{1}{K_{c}}\right\}^{-1} \\
& \text { Close } K_{s}=\left\{\frac{1}{K_{h 1}}+\frac{1}{K_{h 3}}+\frac{1}{K_{c}}\right\}^{-1}
\end{aligned}
$$

ここで、

$K_{h 1}=\frac{12 E I_{h}}{\left(\beta L_{h}\right)^{3}}, \quad K_{h 2}=\frac{12 E I_{h}}{\left\{(1-\beta) L_{h}\right\}^{3}}, \quad K_{h 3}=\frac{4 E I_{h}}{L_{h}{ }^{3}} \frac{A_{1}}{B_{1}}, \quad K_{c}=\frac{\lambda E I_{c}}{L_{c}{ }^{3}}(1-\mathrm{c}, \mathrm{d}, \mathrm{e}, \mathrm{f})$ 
$\lambda$ は野縁受けの材端条件で定まる係数であり、ここでは $\lambda=192$ であ る（両端単純支持の時 $\lambda=48 ） 。 A_{l}, B_{1}$ は回転バネ $k_{\theta}$ および $\alpha, \beta, \gamma$ によ り構成されており、詳細は付録 $\mathrm{A}$ に記した。式（1-a f f ) からハンガ 一接合部の水平剛性 $K_{s}$ は、主にハンガーの要素 $\mathrm{BC}, \mathrm{CD}$ の材端条件 が固定一固定ローラーの曲げ剛性 $K_{h l}$ および $K_{h 2}$ 、野縁受けのねじれ 剛性を含む $K_{h 3}$ 、野縁受けの曲げ剛性 $K_{c}$ の直列関係から表される。 式（1-a）は式（1-b）と異なり $K_{h 2}$ が存在する。これは Open 時に点 $\mathrm{C}$ で離間状態にあるため、要素 $\mathrm{CD}$ の曲げ変形が生じることに由来 している。式（1-a f f) により計算されるハンガー接合部試験体の水 平剛性は ${ }_{\text {ppen }} K_{s}=21 \mathrm{~N} / \mathrm{mm}$ 、 Close $_{s} K_{s}=46 \mathrm{~N} / \mathrm{mm}$ となり、図 10 に理論值 (太 実線）を反映させると、実験および解析值によく対応している。ま た、図 10 の耐力の理論值は、ハンガーのモーメント分布を考慮して ハンガーの崩壊形が図 11 のようになると考え、全塑性モーメントを $M_{p}$ として終局耐力 $H_{u}$ を Open 時は $H_{u}=2 M_{p} / L_{h}$, Close 時は $H_{u}=2 M_{p} /\left(\beta L_{h}\right)$ と計算した結果である。実験および解析では、ひずみ硬化の影響で 理論值を上回っていると考えられるが、およその耐力を捉える意味 では十分に有効的であると考えられる。そのため、野縁受けと野縁 を留めるクリップが強固（耐風圧用、耐震用等）な場合に、本評価 方法が有効であると考えられる。

\section{4. 天井水平剛性の推定法の提案}

\section{1 野縁受けと吊ボルトの材長が吊材の水平剛性に及ぼす影響}

前節において、ハンガー接合部の水平剛性が載荷の向きによって 異なるという力学的特性について明らかにするとともに、それを評 価する力学モデルを構築した。実際の天井では、ハンガーは吊ボル 卜と野縁受けを接合するように設置される。野縁受けおよび吊ボル トの各材長 $L_{c}, L_{b}$ は天井が設置される空間状況によって寸法が多様 に存在する可能性がある。そこで、吊ボルトおよび野縁受けを含め たハンガー接合部からなる系を吊材と称し、野縁受けおよび吊ボル トの各材長 $L_{c}, L_{b}$ が吊材の水平剛性に及ぼす影響について検討する。

\section{1.1 野縁受け材長 $L_{c}$ の影響}

吊ボルトの材長は $L_{b}=0$ とし、ここでは野縁受けの材長 $L_{c}$ がハン ガー接合部の水平剛性 $K_{s}$ に及ぼす影響について検討する。図 13 に その結果を示す。ここで、最終的に天井が組まれた状態を想定して、 $L_{c}$ はハンガーから直ぐ左右にある 2 つのクリップの距離（クリップ 間隔）に相当するものとする。また、本節の検討では、野縁受けの 弱軸曲げを単純梁として扱うこととする。図中の $\square \bigcirc \triangle は$ 、図 8 の 数值解析モデルに吊ボルトに相当する梁要素を付加して水平剛性を 得た結果、線は式 (1-a,b) による結果である。両者はよく一致して おり、本剛性式から数值解析モデルとほぼ同等な結果が得られるこ とを示している。この図から、 $L_{c}$ が長くなるほど剛性が低下し、載 荷の向きによる剛性の差異が小さくなる傾向にあることが解る。全 体の水平剛性 $K_{s}$ に占める各剛性 $K_{i}(i=\mathrm{h} 1, \mathrm{~h} 2, \mathrm{~h} 3, \mathrm{c})$ の割合を図 14 に示 す。 $K_{s}$ に占める $K_{i}$ の割合（図 14 の縦軸）は、式（1-a,b）において 両辺を各々の左辺で除すことで得られる右辺の各項 $K_{s} / K_{i}$ で表され る。 $L_{c}$ が短いときは、 $K_{h 3}$ が支配的になっている。 $L_{c}$ の増加に伴って、 野縁受けの弱軸の曲げ剛性 $K_{c}$ の割合が増加するが、ねじれ剛性低下 の影響を受けて $K_{h 3}$ が占める割合も依然として大きい。一方、Close 時において要素 $\mathrm{BC}$ の曲げ剛性 $K_{h l}$ も全体の水平剛性に大きく寄与 していることが解る。Open 時では要素 CD の曲げ剛性 $K_{h 2}$ の割合が 最大で $3 \%$ と小さいことから、この項を無視した剛性式でも有効で

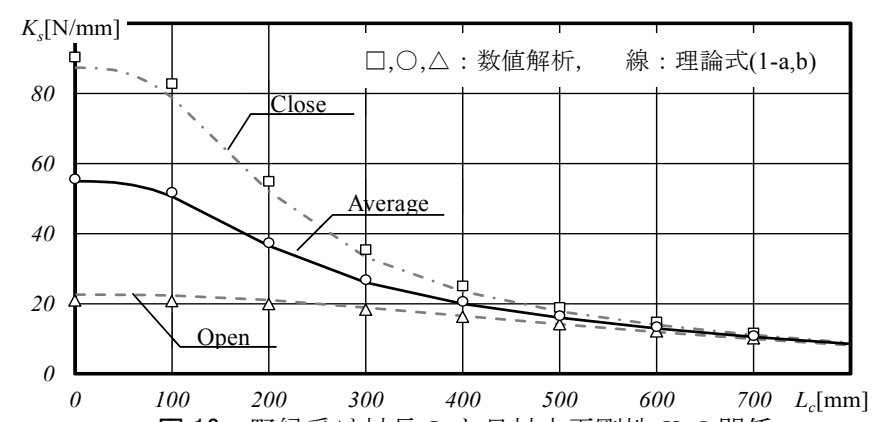

図 13 野縁受け材長 $L_{c}$ 之吊材水平剛性 $K_{s}$ の関係

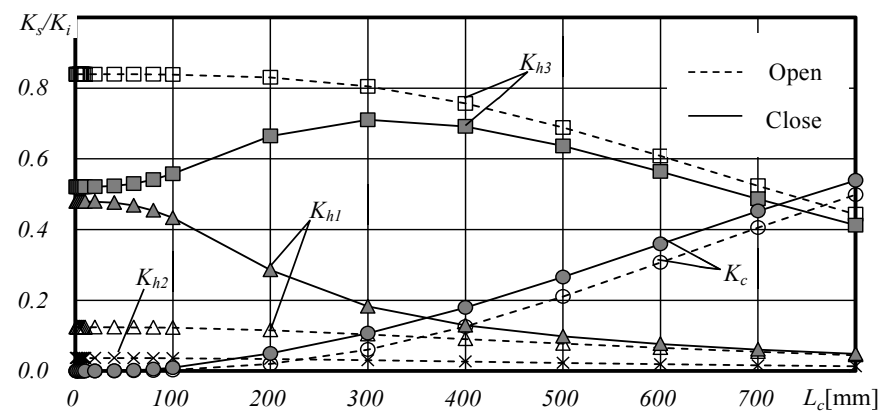

図 $14 L_{c}$ と吊材水平剛性 $K_{s}$ に占める各剛性の割合の関係

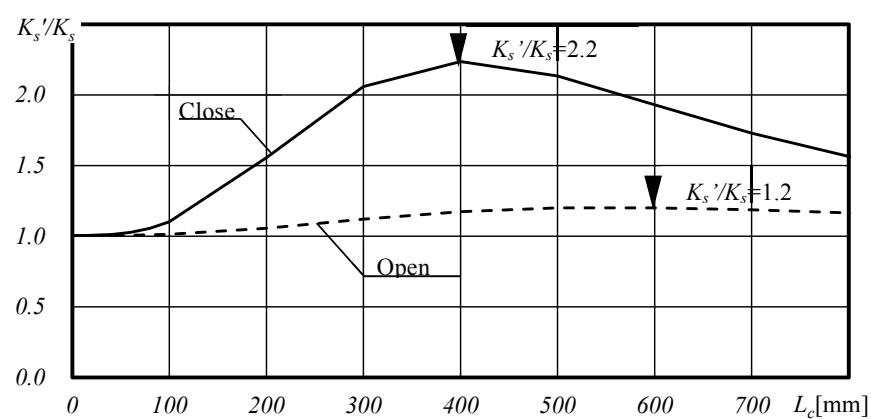

図 15 野縁受けの秝じれ剛性が吊材水平剛性 $K_{s}$ に及ぼす影響

あることが考えられる。次に、野縁受けの水じれ剛性が水平剛性 $K_{s}$ に及ぼす影響について検討する。式（1-a f f ) を用いて、野縁受けの ねじれ変形を無視した水平剛性 $K_{s}$ 'と㸚じれ変形を考慮した水平剛 性 $K_{s}$ とを比較した結果を図 15 に示寸。放じれ剛性を考慮しない場 合、 $K_{s}$ は過大に評価される。しかし、Open 時の $K_{s}{ }^{\prime} / K_{s}$ は最大でも 1.2 倍で、ねじれ剛性の影響が小さい。一方、Close 時では最大 2.2 倍まで過大になり、ねじれ剛性の影響を受けや寸いことが解る。特 に、実際の天井で使用される可能性がある $L_{c}=200 \sim 400 \mathrm{~mm}$ の範囲で 剛性が過大になる傾向にあるため、野縁受けの称じれ剛性を考慮し て剛性評価することは重要である。

\section{1.2 吊ボルト材長 $L_{b}$ の影響}

3 章で構築したハンガー接合部の力学モデルに吊ボルトを付加し、 ハンガー接合部の影響を含めた吊ボルトの水平剛性について検討す る。吊材の水平剛性を式で表すと以下のようになる。

$$
\begin{aligned}
& \text { Open }_{K_{s}}=\left\{\frac{1}{K_{h 1}}+\frac{1}{K_{h 2}}+\frac{1}{K_{h 3}}+\frac{1}{K_{c}}+\frac{1}{K_{b}}\right\}^{-1} \\
& {\text { Close } K_{s}}^{=}=\left\{\frac{1}{K_{h 1}}+\frac{1}{K_{h 3}}+\frac{1}{K_{c}}+\frac{1}{K_{b}}\right\}^{-1}
\end{aligned}
$$

ここで、

$$
K_{h 3}=\frac{4 E I_{h}}{L_{h}{ }^{3}} \frac{A_{1}+\mu A_{2}}{B_{1}+\mu B_{2}}, \quad \mu=\frac{\eta}{\beta} \frac{I_{h}}{I_{b}}, \quad K_{b}=\frac{12 E I_{b}}{\left(\eta L_{h}\right)^{3}}
$$


吊ボルトはハンガーと同様の材料としている。 $I_{b}$ は吊ボルトの断 面 2 次モーメントを示す。 $A_{i}, B_{i}(i=1,2)$ は付録 $\mathrm{A}$ に記す。ハンガ 一接合部の剛性式 (1-a f f) と比べて、吊ボルトの曲げ剛性 $K_{b}$ が追 加され、 $K_{h 3}$ が変化する。式（2-a $\sim \mathrm{e} ）$ を用いて、吊ボルトの材長 $L_{b}$ が吊材の水平剛性 $K_{s}$ に及ぼす影響を表したものを図 16 に示す。な お、野縁受けは $L_{c}=300 \mathrm{~mm}$ の単純梁として扱っている。数值解析結 果（図中の $\square \bigcirc \triangle ）$ と理論解（曲線）がよく一致している。吊ボル トが長くなるほど剛性が低くなり、載荷の向きによる剛性の違いが なくなる傾向にある。図 14 と同様に全体の水平剛性に占める各剛性 項の割合を図 17 に示寸と、 $L_{b}$ とともに吊ボルトの曲げ剛性 $K_{b}$ の割 合が大きくなる様子が解るが、 $K_{h 3}$ の割合はそれ以上に大きく重要な 要素であることが解る。一方、他要素の剛性の割合は概放 $L_{b} \geqq$ $300 \mathrm{~mm}$ で $1 \%$ 以下とほぼ無視できる程度まで小さくなることが解る。

著者らが行ってきた実験では斜め振れ止めの上部における吊りボ ルトの余長 $L_{t}$ はゼロとしているが、実際に天井に斜め振れ止めを設 置する際には、現場における様々な理由から、この余長 $L_{t}$ がゼロと ならない状態も考えられる。そこで、この $L_{t}$ が斜め振れ止め構面の 水平剛性に及ぼす影響について付録 B で検討した結果、斜め振れ止 め構面の水平剛性一及ぼす影響は、 $L_{b}$ に比べて $L_{t}$ の方が小さい傾向 にあり、 $L_{t}$ を無視できる領域があることがわかった（付図 B3）。こ の $L_{t}$ が存在する場合には剛性低下よりも局部的な偏心曲げによる吊 りボルトの疲労破壊が深刻な問題となることから、 $L_{t}$ は小さくする べきであることを付け加えておく。

\section{2 天井水平剛性の簡易評価手法とその妥当性の検証}

天井面が十分に剛体であると仮定した場合、天井を吊っている全 ての吊ボルト水平剛性を総和したものが天井全体の水平剛性に相当 すると考えられる。そこで、ここからは実際に 2 章で用いた天井試 験体の水平剛性について式（2-a e ）を用いて算定し、剛性の評価方 法の妥当性について検討する。試験体の吊ボルトの状況の概念図を 図 18a）として改めて示した。吊ボルト長さ $1370 \mathrm{~mm}$ のもの 12 本で 吊られており、その内 2 本には斜め振れ止めが設けられている。振 れ止めの付く吊ボルトは振れ止めの取付け金具により固定支持され るとみなし、吊ボルトの曲げ剛性 $K_{b}$ に有効な直径は、内径 $7.5 \mathrm{~mm}$ $\left(I_{b}=155 \mathrm{~mm}^{4}\right.$ 相当 $)$ とする。 $L_{c}$ は図 2 から $330 \mathrm{~mm}$ とし、野縁受けの 漦じれならびに曲げに対する材端条件は単純支持とする。その他の 必要な諸元は表 3 と同様とする。

ここで具体的に $L_{b}=200$ の試験体を例に剛性評価を行う。2.2 節で 述べたように 1 質点系とみなした天井の初期剛性は、各変形状態 (Close, Open) における両剛性の平均值で概䄈せる。振れ止めあ り $\left(L_{b}=200 \mathrm{~mm}\right)$ および振れ止めのなし $\left(L_{b}=1370 \mathrm{~mm}\right)$ の水平剛性を ${ }_{A v e} K_{s}^{200},{ }_{A v e} K_{s}^{1370}$ とする。上添え字は $L_{b}$ の值を示す。式（2-a e e に り各吊材の水平剛性を求めると以下のようになる。

$$
\begin{aligned}
& { }_{A v e} K_{s}^{200}=\frac{O_{\text {pen }} K_{s}+{ }_{\text {Close }} K_{s}}{2}=\frac{4.64+5.95}{2}=5.30[\mathrm{~N} / \mathrm{mm}] \\
& { }_{A v e} K_{s}^{1370}=\frac{O_{\text {pen }} K_{s}+{ }_{\text {Close }} K_{s}}{2}=\frac{0.052+0.058}{2}=0.055[\mathrm{~N} / \mathrm{mm}]
\end{aligned}
$$

これらの剛性に各本数を乗じることで天井全体の剛性となるが、 天井は吊構造であるため振り子のみかけ剛性が存在する。この振り 子剛性は吊ボルトに生じる引張軸力および振り子長さにより求めら れる。本試験体の総質量 $(92 \mathrm{~kg})$ は、中央の 6 本の吊ボルトに概放集 中していると考えられる。したがって、中央の 2 本分の ${ }_{A v e} K_{s}^{200}$ およ

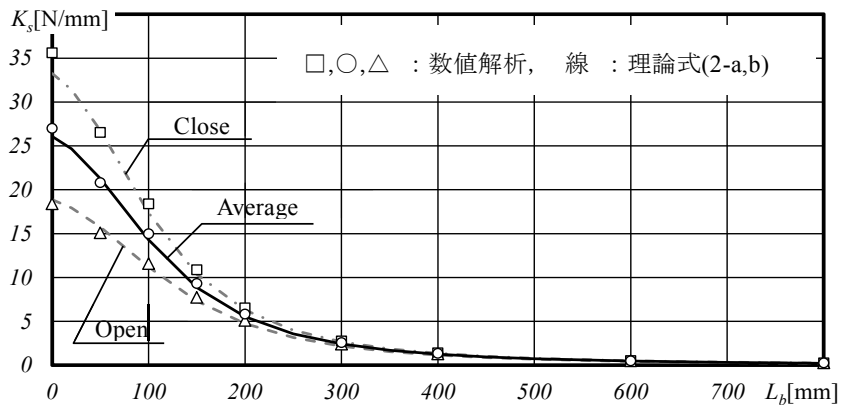

図 16 吊ボルト材長 $L_{b}$ と吊材水平剛性 $K_{s}$ の関係

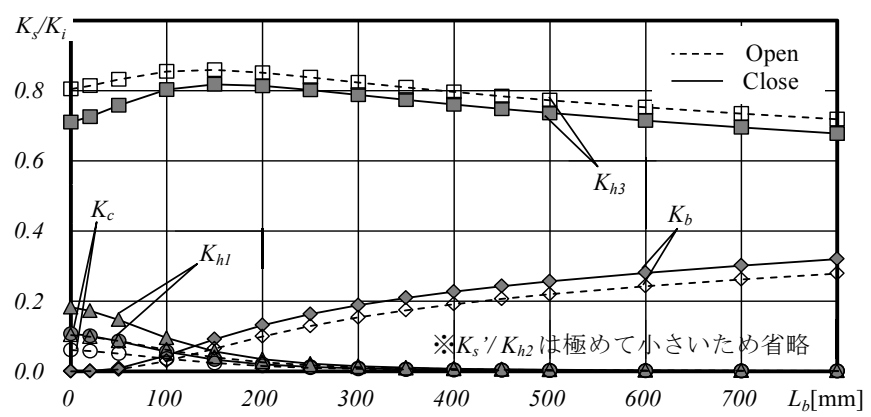

図 $17 L_{b}$ と吊材水平剛性 $K_{s}$ に占める各剛性の割合の関係

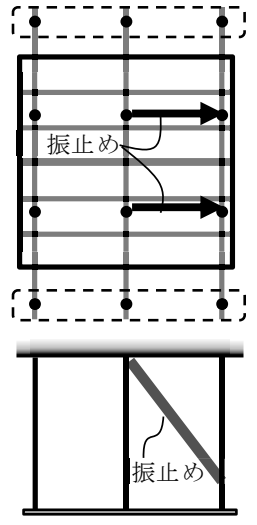

a）吊ボルトの状況

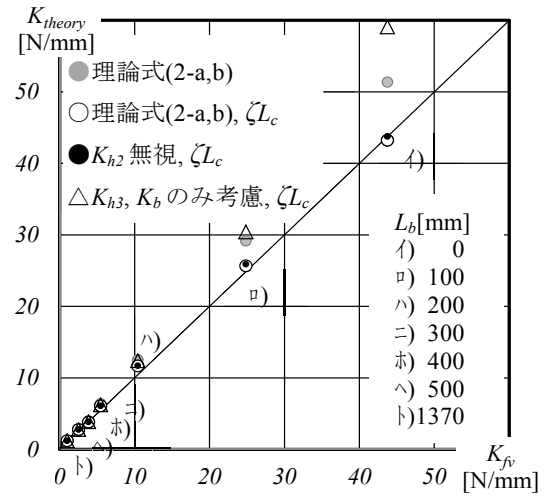

b）相関図
図 18 最小ユニット天井試験体の実験水平剛性と計算值の比較

び 4 本分の ${ }_{A v e} K_{s}^{1370}$ は振り子剛性を考慮し、周囲(図 18a)の点線枠内) の 6 本の ${ }_{A v e} K_{s}^{1370}$ は振り子剛性を考慮しないものとする。1 本辺り負 担する質量を $m \fallingdotseq 15\left[\mathrm{~kg} /\right.$ 本] しし、振り子長さ $L_{p}=L_{b}+L_{h}$ と考えて振り 子剛性を求める。振り子剛性は吊ボルト水平剛性と並列関係にある とみなして、天井全体の水平剛性 $K_{\text {theory }}$ を以下のように算定する。

$$
\begin{aligned}
K_{\text {theory }} & =\left({ }_{A v e} K_{s}^{200}+\frac{m g}{L_{p}^{200}}\right) \times 2+\left({ }_{A v e} K_{s}^{1370}+\frac{m g}{L_{p}^{1370}}\right) \times 4+{ }_{A v e} K_{s}^{1370} \times 6 \\
& =12.24[\mathrm{~N} / \mathrm{mm}]
\end{aligned}
$$

ここで、 $g$ は重力加速度、 $L_{p}$ の上添え字は $L_{b}$ をそれぞれ示す。自 由振動から実際に同定された水平剛性は $K_{f v}=10.44[\mathrm{~N} / \mathrm{mm}]$ であり約 20\%の誤差で評価されたことになる。他の試験体についても同様な 方法で計算した計算結果を $K_{\text {theory }}$ とし、実験值 $K_{f v}$ との相関を図 $18 \mathrm{~b}$ ) の灰色の○で示す。本評価手法による計算值 $K_{\text {theory }}$ と実験值 $K_{f v}$ の間 に相関があるが、どの $L_{b}$ の試験体においても概初等しく $20 \%$ 程度の 誤差があることが伺える。通常、組まれた天井では野縁受けはクリ ップで野縁に連結されるが、クリップおよび野縁は野縁受けの変形 を完全に拘束する剛性は有していないことが考えられる。そのため、 クリップ間隔を直接 $L_{c}$ に採用し、野縁受けのねじれ剛性 $k_{\theta}$ をねじれ 
回転拘束の単純支持とした場合、実際より $k_{\theta}$ が過大に評価されるこ とが考えられる。そこで、 $L_{c}$ を実際より $\zeta$ 倍長く見積もることで、 クリップによる不完全な支持を考慮する。 $K_{\text {theory }}$ と $K_{f v}$ の誤差が最小

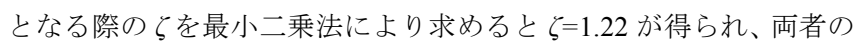
誤差は $10 \%$ 以下となった（図 18b）の白色○)。なお、本章で先述し たように、式（2-a e e) において影響が小さい剛性を除いたもので評 価した結果を黒色の○（K $K_{h 2}$ の久無視 $)$ および $\triangle\left(K_{h 3}, K_{b}\right.$ のみ考慮 $)$ で示した。同図の○と比較して $K_{h 2}$ の影響が小さいことが解る。同 図の $\triangle$ 結果から、 $L_{b}=300$ 以下では誤差が大きいことが解る。

また同様な方法で、規模の大きな天井に対して剛性評価を行った。 対象とした天井は、文献 6) のその 4 で用いられた試験体（天井 1） および付録 C に示したもの（天井 2) である。両者とも振動台実験 に用いられた試験体であり、大きな天井の一部分に相当する。振動 台フレームの制約上、天井 1 で $9 \mathrm{~m}^{2}$ 、天井 2 で $21 \mathrm{~m}^{2}$ となっている。 天井 2 では、振れ止めの数を $10,4,2$ 本と変えて、3 種の剛性（天井 2a,b,c) を取得した。両者、振れ止めの取り付く位置が $L_{b}$ 異なって いる。両対象天井ともハンガーが野縁受けの中央にあり、 $L_{c}=300 \mathrm{~mm}$ となっている。ただし、天井 2 では、最外縁の吊ボルトで野縁受け が $L_{c}=135 \mathrm{~mm}$ の片持梁状態にあるため、野縁受けのねじれ剛性 $k_{\theta}$ お よび曲げ剛性 $K_{b}$ は、 $\zeta=1.22$ 倍した $L_{c}$ の片持梁の材端条件で計算す る必要がある。吊ボルトは先と同様の内径 $7.5 \mathrm{~mm}\left(I_{b}=155 \mathrm{~mm}^{4}\right.$ 相当 $) 、$ 野縁受けおよび八ンガーの諸元は表 3 と同様のものとする。その他、 剛性評価をする上で最低限必要な情報は表 4 に示した。ここでは本 評価法によって計算された剛性を $K_{\text {theory }}$ 、実際に自由振動によって 同定された固有周期と質量から得た剛性を $K_{\text {test }}$ として表す。両者の 間の誤差は、 $20 \%$ 以下で比較的精度よく剛性を評価できている。

\section{5.まとめ}

本研究では、ハンガー接合部の力学的特性を要素実験および数值 解析によって分析し、ハンガー接合部を含めた吊ボルトに対して力 学的モデルを構築することで、野縁方向における天井の水平剛性を 検討した。また、この結果をもとに規模の異なる天井の水平剛性を 評価し実験值と比較することで、本研究で提案した天井の水平剛性 評価法の妥当性を示した。検討によって得られた知見を以下に示す。

1) 天井の野縁方向において、天井の水平剛性は載荷の向きによっ て異なる。特に、吊ボルトの曲げ変形が小さい $\left(L_{b}\right.$ が短い) と き、この傾向が顕著に表れる。

2) 天井の水平剛性が載荷の向きによって異なる特徵はハンガー接 合部にある。これは、非対称な形状をしたハンガー金物が野縁 受けと接触する箇所が、載荷の向きにより異なるためである。

3) 梁要素でモデル化されたハンガーと野縁受けの間に接触要素を 導入することで、ハンガー接合部の挙動および応力状態を再現 することが可能である。

4) 提案した力学モデルから求められる水平剛性式によりハンガー 接合部の水平剛性が算定できる。また、ハンガー金物の崩壊形 式を考慮することで、ハンガーの終局耐力を評価できる。

5) クリップは野縁受けの変形を完全に拘束する剛性を有していな いため、水平剛性 $K_{s}$ を評価する際は $L_{c}$ を $\zeta=1.22$ 倍して評価す る必要がある。

6) 実際の天井で採用される可能性がある $L_{c}=200 \sim 400 \mathrm{~mm}$ において、 野縁受けの水じれ剛性が吊材の水平剛性に及ぼす影響が大きい。
表 4 規模の大きな天井に対する剛性評価

\begin{tabular}{|c|c|c|c|c|c|c|c|c|}
\hline & \multicolumn{2}{|c|}{ 天井1 } & \multicolumn{2}{|c|}{ 天井 $2 \mathrm{a}$} & \multicolumn{2}{|c|}{ 天井 $2 b$} & \multicolumn{2}{|c|}{ 天井 $2 \mathrm{c}$} \\
\hline 質量[kg] & \multicolumn{2}{|c|}{167} & \multicolumn{2}{|c|}{383} & \multicolumn{2}{|c|}{375} & \multicolumn{2}{|c|}{372} \\
\hline 吊ボルト総数 $[$ 本 $]$ & \multicolumn{2}{|c|}{10} & \multicolumn{2}{|c|}{35} & \multicolumn{2}{|c|}{35} & \multicolumn{2}{|c|}{35} \\
\hline$L_{b}[\mathrm{~mm}]$ & 50 & 1370 & 0 & 1370 & 0 & 1370 & 0 & 1370 \\
\hline$L_{c}[\mathrm{~mm}]$ & 300 & 300 & $300(135)$ & $300(135)$ & 300 & $300(135)$ & 300 & $300(135)$ \\
\hline$K_{s}[\mathrm{~N} / \mathrm{mm} /$ 本 $]$ & 18.01 & 0.05 & $21.70(34.75)$ & $0.05(0.06)$ & 21.70 & $0.05(0.06)$ & 21.70 & $0.05(0.06)$ \\
\hline$K_{p}[\mathrm{~N} / \mathrm{mm} /$ 本 $]$ & 1.09 & 0.11 & 1.07 & 1.07 & 1.07 & 1.07 & 1.07 & 1.07 \\
\hline 各吊ボルト本数[本] & 4 & 6 & $6(4)$ & $15(10)$ & 4 & $17(14)$ & 2 & 19(14) \\
\hline$K_{\text {theory }}[\mathrm{N} / \mathrm{mm}]$ & \multicolumn{2}{|c|}{77.40} & \multicolumn{2}{|c|}{210.87} & \multicolumn{2}{|c|}{94.07} & \multicolumn{2}{|c|}{48.79} \\
\hline$K_{\text {test }}[\mathrm{N} / \mathrm{mm}]$ & \multicolumn{2}{|c|}{67.86} & \multicolumn{2}{|c|}{209.41} & \multicolumn{2}{|c|}{79.72} & \multicolumn{2}{|c|}{45.26} \\
\hline 誤差[\%] & \multicolumn{2}{|c|}{14} & \multicolumn{2}{|l|}{1} & \multicolumn{2}{|c|}{-18} & \multicolumn{2}{|c|}{-8} \\
\hline
\end{tabular}

また、 $L_{c}=300 \mathrm{~mm}$ において、 $L_{b} \geqq 300 \mathrm{~mm}$ では吊材の水平剛性 $K_{s}$ に占める $K_{h l}, K_{c}$ の割合がほぼ無視できる程度まで小さくなる。 この条件下であれば、 $K_{h 3}$ と $K_{b}$ だけ考慮した吊材の水平剛性で も概ね対応可能であることを示唆している。

しかし、実際の天井では、ハンガーがクリップに偏って位置して いることもあるため、ハンガーの位置を考慮した検討が今後の課題 として考えられる。

\section{謝辞}

本研究の 2,3 章における実験の遂行とデータ整理および数值解析 モデルの構築は、後藤裕晃氏(2009 年東京工業大学修士修了)に負う ところが大きく、ここに深く感謝の意を表します。また、本論の表 4 に示した実験は、JSPS 科研費 24246094（基盤研究(A)代表者 ; 元 結正次郎）の助成を受けたものならびに国土交通省総合技術開発プ ロジェクト「高強度鋼等の革新的構造材料を用いた新構造建築物の 性能評価手法の開発」天井 WG (主査 元結正次郎)における活動の 一環としておこなったものです。ここに謝意を表します。

\section{参考文献}

1) 日本建築学会：2011 年東北地方太平洋沖地震災害調査速報, 2011.7.

2) 日本建築学会 非構造部材（屋根, 外壁, 天井）の地震・風による被害の軽 減化特別研究委員会 : 非構造部材（屋根, 外壁, 天井）の地震・風による 被害の軽減化の研究, 2008

3）文部科学省：学校施設における天井等落下防止対策のための手引,2013,8

4) 国土交通省国土技術政策総合研究所他：建築物における天井脱落対策に 係る技術基準の解説, 2013.10

5) 日本工業規格：建築用鋼製下地材（壁・天井）JIS A6517 用准施工要領書 平成 17 年版

6) 後藤裕晃, 元結正次郎, 佐藤恭章他：鋼製下地在来工法天井の動的特性 その 1 6 日本建築学会大会学術講演梗概集 B-1, pp.829-836, 2009.08

7) 森田佑輔, 元結正次郎, 吉川昇他: クリップの素材試験およびクリップ接 合実験概要 日本建築学会大会学術講演梗概集 B-1, pp.807-808, 2008.09

8) 桑村仁：鋼構造の性能と設計，共立出版株式会社, 2002.11

\section{付録 $\mathrm{A}$ ハンガー接合部の力学モデルで成立する条件式と剛性式 $K_{s}$ の詳細}

3.3 節で示したハンガー接合部の力学モデルにおいて成立する釣合式およ び適合条件式について述べる。なお、ここでは図 12 のハンガー接合部の力学 モデルに吊ボルトに相当する要素 $\mathrm{OA}$ を点 $\mathrm{A}$ から上に付加したモデルを想定 する。吊ボルトの材長を $L_{b}=\eta L_{h}$ で表し、吊ボルトの断面 2 次モーメントを $I_{b}$ で表す。吊ボルトの上端（点 $\mathrm{O}$ ）を固定ローラー支持とし、点 $\mathrm{O}$ に荷重 $H$ が 作用する場合について釣合条件式および適合条件式を立て、たわみ角法によ り解く。各材端モーメントの式はここでは省略する。各要素の材端モーメン トおよびせん断力を $M_{i j}, Q_{i j}(i, j=\mathrm{O} \sim \mathrm{E})$ で示すと、このモデルにおける各節点方 程式および各部材のせん断力は以下のようになる。

$M_{o a}+M_{a b}=0, \quad M_{b a}+M_{b c}=0, \quad M_{c b}+M_{c d}=0, \quad M_{d c}+M_{d e}=0 \quad$ (A.1-a $\left.\sim \mathrm{d}\right)$

$Q_{a b}=Q_{d e}=0, Q_{o a}=Q_{b c}=H, Q_{c d}=\left\{\begin{array}{cc}H & (\text { Open }) \\ \text { Unknown } & (\text { Close })\end{array}\right.$

(A.1-e $\sim$ g) 


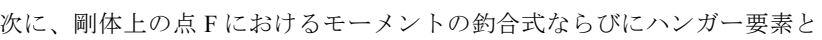
剛体の間に成立する適合条件式を、ハンガーの各変形状態に対して考える。 Open 時: $H \frac{(1-\beta) L_{h}}{2}+M_{e d}+k_{\theta} R_{e f}=0, \theta_{e}=R_{e f}$

Close 時: $\left(Q_{c b}+Q_{c d}\right) \frac{(1-\beta) L_{h}}{2}-Q_{d c} \frac{(1-\beta) L_{h}}{2}+M_{e d}+k_{\theta} R_{e f}=0, R_{c d}=R_{e f}$

$\theta_{e}$ は要素 $\mathrm{DE}$ の回転角、 $R_{c d}, R_{e f}$ は要素 $\mathrm{CD}$ および剛体の部材角、 $k_{\theta}$ は回転バ ネ剛性をそれぞれ示す。以上の条件式から、たわみ角法により導かれる水平 バネ FG を含めた水平剛性式を以下に示す。

$$
\begin{aligned}
& \text { open }_{s}=\left\{\frac{1}{K_{h 1}}+\frac{1}{K_{h 2}}+\frac{1}{K_{h 3}}+\frac{1}{K_{c}}+\frac{1}{K_{b}}\right\}^{-1} \\
& \text { Close } K_{s}=\left\{\frac{1}{K_{h 1}}+\frac{1}{K_{h 3}}+\frac{1}{K_{c}}+\frac{1}{K_{b}}\right\}^{-1}
\end{aligned}
$$

ここで、

$K_{h 1}=\frac{12 E I_{h}}{\left(\beta L_{h}\right)^{3}}, K_{h 2}=\frac{12 E I_{h}}{\left\{(1-\beta) L_{h}\right\}^{3}}, K_{h 3}=\frac{4 E I_{h}}{L_{h}{ }^{3}} \frac{A_{1}+\mu A_{2}}{B_{1}+\mu B_{2}}, \mu=\frac{\eta}{\beta} \frac{I_{h}}{I_{b}} \quad($ A. $4-\mathrm{a} \sim \mathrm{d})$ $K_{c}=\frac{\lambda E I_{c}}{L_{c}{ }^{3}}, \quad K_{b}=\frac{12 E I_{b}}{\left(\eta L_{h}\right)^{3}}$

(A.4-e,f)

$A_{l}=\left\{k_{\theta} L_{h}(\alpha+\gamma+1)+E I_{h}\right.$

(A.5-a)

$A_{l}=\left\{k_{\theta}\{4(\beta+\alpha)(3 \gamma+1-\beta)+(1-\beta)(4 \gamma+1-\beta)\} L_{h}+4 E I_{h}(3 \gamma+1-\beta)\right.$

(A.5-b)

$A_{2}=\left\{\begin{array}{l}k_{\theta} \beta L_{h} \\ 4 k_{\theta}(3 \gamma-\beta+1) \beta L_{h}\end{array}\right.$

(A.6-a)

(A.6-b)

$B_{I}=\left\{\begin{array}{c}k_{\theta} L_{h}\{\alpha+4 \alpha \gamma+\gamma+\beta(1-\beta)(\alpha+\gamma+1)\} \\ \quad+E I_{h}\left\{\beta+\gamma(1-\beta)^{2}+\alpha(1+\beta)^{2}\right\} \\ k_{\theta}\{12 \alpha \gamma+4 \alpha(1-\beta)(\gamma+1)+\beta(1-\beta)(4 \gamma+1-\beta)\} \beta^{2} L_{h} \\ \quad+E I_{h}\left[(4 \gamma+1-\beta)(1-\beta)^{3}+4(3 \gamma+1-\beta)\left\{\beta+\alpha(\beta+1)^{2}\right\}\right]\end{array}\right.$

$B_{2}=\left\{\begin{array}{l}k_{\theta} \beta L_{h}\left\{\alpha \eta^{2}+(1-\beta) \beta+(\eta+1)^{2}+\gamma(\eta+2)^{2}\right\}+\beta E I_{h}(\eta+\beta+1)^{2} \\ k_{\theta} \beta L_{h}\left[(4 \gamma+1-\beta)(1-\beta)(\eta+2 \beta)^{2}+4(3 \gamma+1-\beta)\left\{\beta(\eta+\beta)^{2}+\alpha \eta^{2}\right\}\right] \\ \quad+4 E I_{h} \beta(3 \gamma+1-\beta)(\eta+\beta+1)^{2}\end{array}\right.$

${ }_{0}{ }_{p e n} K_{s}$, Close $_{s}$ はそれぞれ Open 時およびClose 時の水平剛性を示す。 $A_{i}, B_{i}(i=1,2)$ において、ハンガーの Open 時の水平剛性には式（A.5 8-a）を、Close 時には 式(A.5 8-b) を用いる。吊ボルトの材長が $L_{b}=0$ のとき、式(A.3-a,b)の $1 / K_{b}=\mu=0$ となり、吊ボルトを除いたハンガー接合部の水平剛性が得られる。

\section{付録 B 斜め振れ止め上部の吊ボルト余長の影響}

$L_{t}$ が斜め振れ止め構面の水平剛性に及ぼす影響について検討を行う。著者 らの実験で用いた試験体では、付図 B1b）のような取付金具を用いて斜め振 れ止めを設置している。この取付金具により斜め振れ止めの端部は吊ボルト に対してボルトA でピン接合のような形となる。しかし実際は、電動ドライ バーによりボルトを締め付けるため、取付金具を構成する 3 つのプレート間 に比較的大きな摩擦力が生じ、ボルト A 材軸まわりの曲げモーメントに対し てある程度抵抗することが考えられる。そこで、斜め振れ止めの両端は剛接 合として扱うこととする。一例として、 $L_{t}=L_{b}=400 \mathrm{~mm}$ の斜め振れ止め構面の 水平剛性 $K_{B r}$ を数值解析により求めると、 $\left({ }_{\text {open }} K_{B r},{ }_{\text {close }} K_{B r}\right)=(1.04,1.12)[\mathrm{N} / \mathrm{mm}]$ と得られる。このときの斜め振れ止め構面のモーメント分布は付図 B2 のよう になる。この分布は、斜め振れ止め下端の取付金具と吊ボルトの境で生じる モーメント值を基準としたモーメント比で表している。付図 B1a）の部位(2) (3)に相当する部位で、吊ボルトの境界条件を固定一固定ローラーとした曲げ モーメントに類似している。ここで、取付金物周りの回転角が水平剛性に及 ぼす影響も考えられるが、水平剛性 $K_{B r}$ を図 B1a）ような部位(1)〜(3)の各水平 剛性で簡易的に表すと以下のようになる。

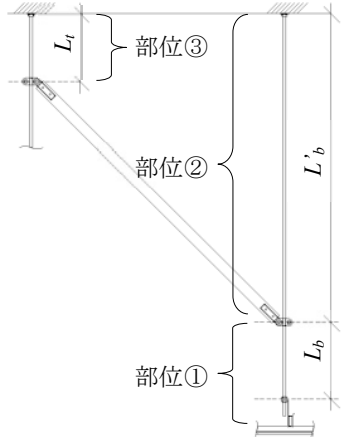

a）斜め振れ止め構面

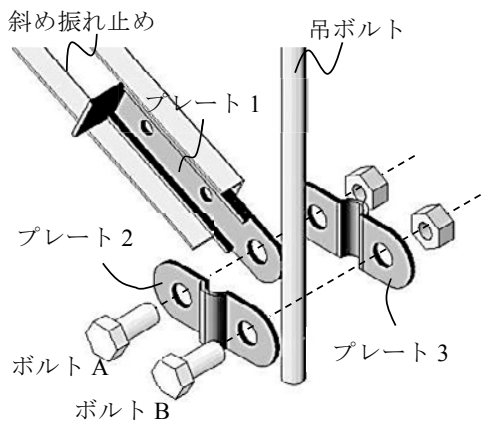

b）斜め振れ止め取付金物 付図 B1 斜め振れ止め構面の概要

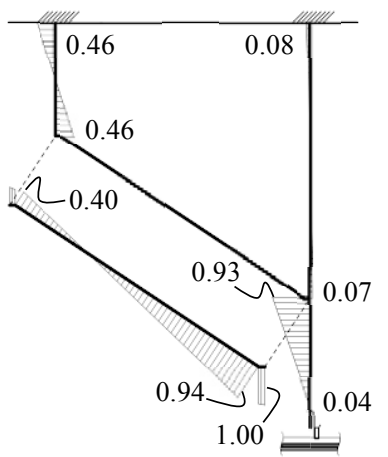

付図 B2 モーメント分布図

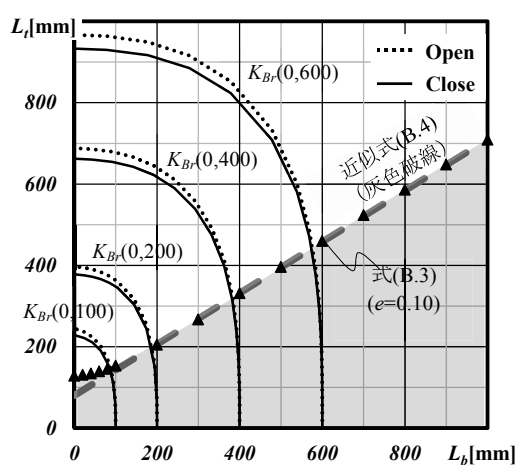

付図 B3 $L_{t}-L_{b}$ 相関関係図
$K_{B r}\left(L_{t}, L_{b}\right)=\frac{1}{K_{s}\left(L_{b}\right)^{-1}+\left\{K_{s}^{\prime}\left(L_{b}^{\prime}\right)+K_{t}\left(L_{t}\right)\right\}^{-1}}$

(B.1-a)

$K_{s}\left(L_{b}\right)=$ open $_{s} \quad$ or $\quad$ Close $K_{s} \quad, \quad K_{s}^{\prime}\left(L_{s}^{\prime}\right)=\frac{12 E I_{b}}{L_{b}^{\prime 3}} \quad, \quad K_{t}\left(L_{t}\right)=\frac{12 E I_{b}}{L_{t}{ }^{3}}(\mathrm{~B} .1-\mathrm{b} \sim \mathrm{d})$

ここで、 $K_{B r}\left(L_{t}, L_{b}\right)$ は斜め振れ止め構面の水平剛性、 $K_{s}\left(L_{b}\right), K_{s}^{\prime}\left(L_{b}^{\prime}\right)$, $K_{t}\left(L_{t}\right)$ はそれぞれ部位(1)〜(3)の水平剛性、 $L_{b}^{\prime}$ は部位(2)の吊ボルトの材長であ る。なお、 $K_{s}\left(L_{b}\right)$ は 4.1.2 節の式 (2-a,b) に等しい。式 (B.1-a) では、 $L_{t}=L_{b}=400 \mathrm{~mm}$ のとき ${ }_{\text {open }} K_{B r}$, close $\left._{B r} K_{B r}\right)=(0.98,1.13)[\mathrm{N} / \mathrm{mm}]$ となり、先程の数值解析で得られる 值を概ね捉えている。この種の斜め振れ止め取付金具に関しては、取付金物 周りの回転角が $K_{B r}$ に及ぼす影響を無視した式（B.1-a）でも概ね有効である ことがわかる。 $L_{t}$ が $K_{B r}$ に及ぼす影響について検討するために式（B.1-a $\sim \mathrm{d} ）$ を用いて、 $K_{B r}\left(L_{t}, L_{b}\right)$ が一定となる $L_{t}$ と $L_{b}$ の平面における等值線を付図 B3 に点線(Open)と実線(Close)で示した。なお、部位(2)は部位(1)と (3)に比べて剛 性が低い傾向にあるため $K_{s}^{\prime}=0$ とした。図中には、 $K_{B r}\left(L_{t}, L_{b}\right)$ が $K_{B r}(0,100)$, $K_{B r}(0,200), K_{B r}(0,400), K_{B r}(0,600)$ の場合について示している。

次に以下で定義される $K_{B r}\left(L_{t}, L_{b}\right)$ と $K_{s}\left(L_{b}\right)$ の誤差 $e$ を導入する。

$$
e=1-\frac{K_{B r}\left(L_{t}, L_{b}\right)}{K_{s}\left(L_{b}\right)}
$$

上式に式（B.1-d）を代入して、L $L_{t}$ をついて解くと次式が得られる。

$$
L_{t}=\sqrt[3]{\frac{12 E I_{b}}{\left(e^{-1}-1\right) \cdot K_{s}\left(L_{b}\right)}}
$$

$e=0.10$ の時、式（B.3）を用いて $L_{t}$ と $L_{b}$ の関係を求めた結果を付図 B3 の $\mathbf{\Delta}$ 印 で示す。ただし、Open とClose で差が小さいために、ここでは両者の平均值 を採用した。この結果において、例えば $L_{t}=395, L_{b}=500$ のとき、 $K_{B r}(395,500)$ は $K_{B r}(0,500)$ と誤差 $10 \%$ にる。このとき $K_{t}\left(L_{t}\right) / K_{s}\left(L_{b}\right)=8.98$ で、 $K_{t}\left(L_{t}\right)$ は $K_{s}\left(L_{b}\right)$ に比べて剛性が高く、 $L_{t}$ の $K_{B r}\left(L_{t}, L_{b}\right)$ への影響が小さい傾向にある。 また、 $L_{t}$ と $L_{b}$ の組合せが付図 B3 の灰色で塗潰した領域にあるとき、誤差が $10 \%$ 以下となる。この付図 B $3 \mathbf{\Delta}$ 印を直線で近似すると、以下のようになる。

$$
L_{t}=0.63 L_{b}+80
$$

式 (B.4) は、部位(3)の影響を無視できる最長の $L_{t}$ を求める際の簡易式となる。 


\section{付録 C 振動台実験に使用された天井試験体の概要}

天井 2 は、振動台実験の際に振動台上に組まれた鉄骨治具フレームから吊り 下げられた試験体である。天井に使用された部材は、すべて JIS にて規定さ れるものを用いており、どれも 2 章の静的加力実験で用いた試験体と同様の 断面である。各々の天井面は厚さ $12.5 \mathrm{~mm}$ の石膏ボード 2 層貼りで、天井の 総質量は下地材を含めて $383 \mathrm{~kg}$ であった。吊ボルト間隔は $900 \mathrm{~mm}$ 、野縁間隔 は $300 \mathrm{~mm}$ として配置されている。天井懐は約 $1500 \mathrm{~mm}$ である。また吊ボルト の吊元は、鉄骨治具フレームの溝形鋼の上下フランジにナットで完全固定支 持されている。斜め振れ止めの取り付け方法は、2 章の静的加力実験と同様 である。この試験体 1 体において、付図 $\mathrm{C} 1$ 中の矢印で示す斜め振れ止めの数 を $10,4,2$ 本と変えることで、天井の水平剛性を変化させた。10 本のときは 図に記した全ての箇所、4 本のときは点線の矢印、2 本のときは一点鎖線の矢 印のついた箇所に振れ止めを入れた。天井の固有振動数は、以下に示す減衰 自由振動の理論式、

$$
u^{\prime \prime}=u_{0} \cdot e^{-h \varpi t} \cdot \cos \left(\varpi \sqrt{1-h^{2}} t-\phi\right)
$$

を最小二乗法により、天井を自由振動させたときに計測された天井面の応答 加速度波形に近似させることで同定した。その結果、天井 $2 \mathrm{a}$ は $3.72 \mathrm{~Hz}$ 、天井 $2 \mathrm{~b}$ は $2.32 \mathrm{~Hz}$ 、天井 $2 \mathrm{c}$ は $1.76 \mathrm{~Hz}$ と同定された。この天井の野縁方向における 水平剛性は、質量と固有振動数から計算される。
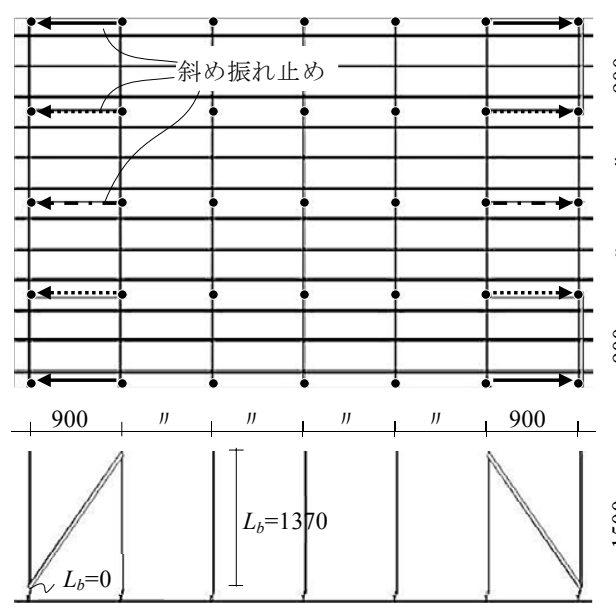

付図 $\mathrm{C} 1$ 天井 2 の平面および立面図

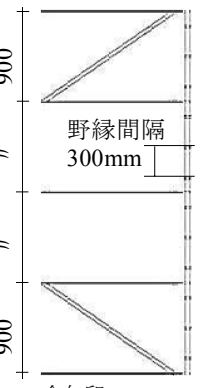

全矢印 :

振れ止め 10 本 (天井 2a) の時 振机止め 4 本 (天井 2b) の時 $\overrightarrow{-} \rightarrow$ :

（2013年11月10日原稿受理， 2014年 5 月27日採用決定） 